\title{
Algeria: Between Transformation and Re-Configuration
}

\section{Rachid Ouaissa}

Since February 16, 2019, millions of Algerians of all generations and from all regions of the country began protesting the regime that has governed the country since Algeria'sindependence in 1962. The protests began in soccer stadiums, in 2018, before reaching smaller urban centers. Of these, the first demonstration was held in the town of Kherrata, in the Kabylie region, best known as the site of the May 1945 massacres. The movement spread from there to all of the country's forty-eight districts as well as Algerian diaspora communities in France, Canada, Austria, Belgium, UK, and the United States. (The diaspora's involvement added a new element that had been largely absent from the events of the 2010-11 Arab Spring.) These mobilizations were spontaneous, non-hierarchical, unstructured, and they lacked a set ideology. Hirak, as Algerians call the February 16 Movement, is a popular movement that transcends all party-political structures and crosses regional, ethnic, and ideological lines. Although it spans all social strata and age groups in Algerian society, Hirak is largely championed by students, lawyers, teachers, civil servants, and members of the liberal professions, which makes it a middle-class movement.

In its first stage, this protest movement arose in opposition to Abdelaziz Bouteflika's candidacy for a fifth term as president, opposing his plans to hold onto power. Then, it went to denounce the whole political regime, demanding a new civilian republic based on the rule of law and democratic principles. The slogan Yetnahaw gaâ [They All Should Go] was coined by a young Algerian in the local vernacular, who said it into the microphone of a news broadcaster from Abu

R. Ouaissa $(\triangle)$

Centrum für Nah- und Mittelost Studien, Philipps-Universität Marburg,

Marburg, Germany

e-mail: ouaissa@staff.uni-marburg.de

(C) The Author(s) 2021

R. Ouaissa et al. (eds.), Re-Configurations, Politik und Gesellschaft des Nahen

Ostens, https://doi.org/10.1007/978-3-658-31160-5_4 
Dhabi on the day of Bouteflika's resignation, insisting that Classical Arabic was not his native language. The slogan has become a rallying cry for the movement in its appeal for a complete overhaul of the system.

After the army forced President Bouteflika to resign on April 2, 2019, he was replaced by Abdelkader Bensalah, as interim president, and a new election was announced for July 4, 2019. On June 1, the Constitutional Council postponed the election. In September 2019, with protests ongoing, the army rescheduled it for December 12, 2019. The five candidates that remained in November 2019 were figures from the regime. More than $60 \%$ of the population boycotted the election, which also had record numbers, $12,76 \%$ of abstentions and blank ballots. Although Abdelmadjid Tebboune was officially elected in the first round of voting with $58.13 \%$ of votes cast, he remains a contested, illegitimate president in the eyes of Algerians, and the protest movement has been unrelenting in its demands for a real democratic transition. And so, the conflict has heightened between the society and le pouvoir (literally "the power," the political and military decision-makers de-facto ruling the country). Two contradictory political projects, two visions of the state, and two perspectives on the relationship between the state and its citizens are in competition: on one side, a project to re-configure le pouvoir with a few cosmetic changes, and on the other, a project to radically transform the foundations of the Algerian state and to undertake a genuine democratic transition.

This idea of re-configuration is inspired by the German sociologist Norbert Elias's principle of "figuration," (Elias 2003) which describes the crystallization of mutually dependent relationships between actors, forming interdependent networks marked by an unstable balance of forces. The re-configuration of a political system designates a process of both conflictual and cooperative interactions seeking to reestablish or uphold the old order. In this sense of the word, re-configuration refers to the process of changing, co-opting, or eliminating actors in order to build new alliances: "changing everything so that nothing changes." The disruptions that occurred in Algeria's pouvoir starting in April 2019, including the choice of a new president, were thus no more than a re-configuration.

"Transition", by contrast, denotes a shift from an authoritarian system to a democratic one. A democratic transition means leaving behind the old political rules of the game and brings about the emergence of new political actors. In the words of Juan Linz and Alfred Stepan, "A democratic transition is completed when sufficient agreement has been reached about political procedures to produce an elected government, when a government comes to power that is the direct result of a free and popular vote, when this government de facto has the authority to generate new policies, and when the executive, legislative and juridical power 
generated by the new democracy does not have to share power with other bodies de jure" (Linz and Stepan 1996, p. 3).

To understand two conflicting dynamics that have dominated Algerian politics since independence-transition and re-configuration-one must understand the internal mechanisms and logics of the Algerian regime. This requires understanding the nature of le pouvoir, the workings of the state in Algeria, and the nature of the pact between state and society since the country's independence in 1962.

This chapter will analyze the power structure of Algeria and discuss the background and different stages of the movement of February 2019. My main thesis in this chapter is that the Algerian regime generally outlasts crises of co-option thanks to its nature as a rentier state, but that this time, unlike during previous crises, the regime has lost the support of the middle classes. That has frustrated its efforts to re-configure the system and increased the likelihood of a democratic shift.

\section{The Nature of the State in Algeria}

The German political scientist Hartmut Elsenhans describes what Algerians colloquially call le pouvoir using the concept of the "state class." According to Elsenhans, the state class comprises the people at the top levels of the bureaucratic hierarchy who, solely by virtue of their positions, extract a collective surplus in the form of rent (Elsenhans 1996, p. 176). The state class reproduces itself out of its own ranks via nepotism, the education system, and bonds of patronage (Elsenhans 1996, p. 200). The members of the state class are organized into clans. These consist of small groups of actors bonded by underlying trust factors, which, by Khaldounian logic, can include parentage, regionalism, family, having attended the same zāwiyya or military academy, and so forth. A clan can include both civilians and military officers, apparatchiks and businesspeople, members of the independence war generation and members of younger generations. The different clans compete over influence, income, and prestige. They form coalitions with other clans in the state class, which often causes the state class to grow in number while increasing how many people are connected to those clans through organic, clientelistic relationships. As a function of their political clout, the clans position themselves at various distances from the central clan. The different clans of the state class, despite coming from basically oppositional ideologies, are connected and united by rent and its distribution. As Mahfoud Bennoune has put it, they therefore reach a consensus to ensure "the equilibrium of stagnation" (Bennoune 1998, p. 17). 
Without delving into the ramifications and history of the economic notion of "rent," I will build the rest of my argument around the concept of the rentier state. The lens of rent helps explain the nature of the cyclical crises of the Algerian regime as well as the crisis in the relationship between state and society in Algeria. Algeria is a quintessential rentier state. Petroleum and natural gas comprise 97\% of exports, $35 \%$ of GDP, and $75 \%$ of budgetary revenue (Crisis Group 2018, p. 3).

Rent is the outcome of restrictions on competition, whether caused by natural monopolies or by politically generated restrictions to the market. It influences political structures and therefore actors' strategies. Unlike profit, capital in the form of rent does not accumulate by market mechanisms. In rent-dominated economies, surplus financial resources are not necessarily invested productively in accordance with economic rules. Consolidating revenue from rent at the state level allows the regime to buy the masses' loyalty while preserving a high level of autonomy from society. Through rent, other social groups and classes are linked to the state by bonds of clientelism, which makes it difficult if not impossible for an autonomous civil society to take shape. Besides breeding clientelization, rent enables the state to build up harshly repressive structures. For Michael Ross, states with large budgets funded by petroleum revenue are more likely to be authoritarian than states with relatively low taxpayer-funded budgets. Unlike other types of rent, petroleum rent calls for a strongly centralized state while encouraging diversity among the ruling elite (Ross 2001, p. 335). The true goal of the ruling class is not development, but a stronghold on maximum power.

The third effect of rent is the dismantling of economic structures, which prevents the development of the capitalism's historical prerequisites: the blossoming of a productive middle class that would pose a social counterweight to the rentier state class. Compared to profit, the accumulation of rent demands different types of monopolies or political access. However, profits in free-market systems ultimately are reinvested because of market competition. As a result, the most powerful capitalists are threatened by any impediments to innovation and quickly leave the market. Businesspeople invest because they expect greater demand from consumers. The innovation-driven competition caused by investments brings not only technical superiority, but real wage growth. Under Keynesian dynamics, real wage growth leads to a rise in demand and therefore gives labor bargaining power. Labor's attainment of autonomy prevents the supremacy of the powerful. It is also the basis of the bourgeois revolution, thus also a prerequisite for the establishment and of democratic structures and civil rights. Large segments of society benefit from the expansion of the market which leads to what Eric Hobsbawm described as the self-disempowerment of the aristocracy (Hobsbawm 
1987) after Europe's industrialization. Besides shaping the political behavior of the elites, capitalist structures also determine the cultural behaviors of society. The mobilization of labor via bargaining power-rather than any kind of ethnic, religious, or clan-based solidarity-becomes workers' preferred conduit for asserting their interests. This is what Ferdinand Tönnies described as the transition from community (Gemeinschaft) to society (Gesellschaft) (Tönnies 2012).

In short, rentier societies are societies in which classes that obtain their privileges by accumulating profit_-i.e., from the market—are marginal or nonexistent. Protecting the accumulation of capital by market mechanisms-i.e., by competition and not via bureaucratic mechanisms or arrangements with the political class-would mean participating in the system of production and therefore in job creation. Algeria does not have a social class that accumulates its capital through production. Obtaining bourgeois status, or simply wealth, depends on relationships between businesspeople and the political power.

After 1962, le pouvoir in Algeria was upheld by an alliance between the military and the party, with its satellites and its bureaucracy, which made the democratization process twice as difficult. Since the economy opened up in the 1990s, compradors have joined these groups as economic actors. The alliance of these three groups of actors under the auspices of the military creates what the British anthropologist Ernest Gellner called "the neo-Mamluk state" (Gellner 1981, p. 64). Yet there are three necessary conditions for a transition: divorcing the army from politics, severing ruling parties from their satellite organizations, and wresting rent from the hands of le pouvoir.

Thus, like all state institutions, the Algerian army is dependent on rent from fossil fuels, but the army is also the institution that holds the monopoly on violence in the Weberian sense. For this reason, this institution has been the backbone of the Algerian state class ever since independence. That is why each of the different clans is grouped around military actors.

The ruling elite clientelizes social groups by creating jobs-the marginal workforce-and subsidizes most consumer goods. At the same time, social services, free education, health care, and the like all lead to the emergence of large middle classes. However, these new marginally employed middle classes are not oriented to or associated with the market in the Weberian sense: their eyes are on rent. In the Algerian case, I have termed those the "trabendo" ${ }^{1}$ middle classes" (Ouaissa 2018). They consume more than they produce, so their social status depends on the share of the surplus that the ruling class spends on consumption. These middle classes are not the result of an increased consumption dependent on production, but on consumption financed by rent. Meanwhile, they exert indirect pressure on the ruling elite to spend even more on consumption. It is those same 
middle classes, which mostly consist of consumers dependent on rent, who have often played the rebels in Algerian history.

Given their dependence on the international price of hydrocarbons, rentier countries experience cyclical crises. Not only do these crises disrupt the power balance between the clans that make up the state class, and often trigger implosions within that class, but they also cause distortions in the state class's relationship with the middle class.

The clientelistic relationship between the middle class and the state began to erode when oil prices dropped in the early 1980s. Algeria's petroleum revenues fell by half between 1980 and 1992, and the budgetary deficit reached 13.7\% in 1988 (Nashashibi et al. 1998). The gross national debt ballooned from 19 billion dollars in 1980 to around 27 billion in 1988. Meanwhile, the Algerian population grew from approximately 18.7 million to 24 million, which corresponds to a very rapid growth rate of $3 \%$ p.a. Two other statistics can be seen as key indicators of the political disaster of the 1990s: the roughly $4.8 \%$ annual increase in the urban population from 1980 to 1990 and the large share of children under 15, which was about $40 \%$ of the national population (Nashashibi et al. 1998). This situation forced the government to launch austerity programs and budget cuts, including slashes to subsidies. Those measures increasingly impoverished the Algerian middle class and led to riots all across the country, culminating in the events of October 1988. The riots were spawned by the gap between the regime and society, but also by an inner split within the regime between the faction of le pouvoir that wanted to reform the system and those anti-reformers who wanted merely just to change the rules of the game.

The Algerian state class responded to the 1988 revolts with two different strategies for revising the social contract between the middle class and le pouvoir. On one hand, the government adopted a policy of privatization and abandoned the discredited socialist model. On the other, it launched controlled political reforms that paved the way to party pluralism. This development was pioneered by the Islamist movement, which founded a party called the Islamic Salvation Front (FIS for short-here and below, I will use the French acronyms for names of parties). The discontent of big swathes of the middle class played out in a growing support for political Islam, as seen in the legislative election of December 1991, when the FIS attained $47 \%$ of the vote and 188 of 430 parliamentary seats. The party became not only a mouthpiece for marginalized sectors of society, but also a gathering place for middle-class Algerians who feared for their status and felt that their progress was being thwarted.

The military reacted to the FIS victory by overthrowing President Bendjedid in a January 1992 coup d'état. The ban on FIS, the radicalization of its compo- 
nent groups, and the le pouvoir repression campaign led the country into a civil war that would last nearly ten years. The FIS split along sociological lines: the marginalized elements, who formed the GIA (Armed Islamic Group), and the religious middle classes, who founded the AIS (Islamic Salvation Army). A merciless war began between various factions. Besides the offshoots that seceded from the Islamic groupings, the war also gave rise to assorted resistance groups.

The civil war of the 1990s and the recourse to physical violence enabled the state class to restore itself. The regime shed its socialist and anti-capitalist ideology and opened up the country economically. On a political level, the state class ended the longstanding monopoly of the FLN (National Liberation Front) as the civilian face of le pouvoir. The multiparty system increased the number of clusters that the state class could co-opt. Besides the fragmented offspring parties of the FLN itself, such as the RND (Democratic National Rally), there were now Islamist parties such as the MSP (Movement for the Society of Peace) and secular parties such as the RCD (Rally for Culture and Democracy). The 1990s civil war permitted a self-re-configuration of the system.

When Bouteflika took power in 1999, sanctified by higher oil prices, the stage was set for a new economic elite and a new kind of politics. Under Bouteflika, an alliance between the military, the business community, and the political wing of le pouvoir turned Algeria into a "neo-Mamluk" state, Gellner's term for a system dominated by an alliance of technocrats, the military, and politicians who are segregated from society by their privileges and caste behaviors (Gellner 1981, p. 64).

From 1999 onward, more than a trillion dollars were spent: not on modernizing the economy, but on expanding clientelism networks and reestablishing peace. With Bouteflika's rise to power, thanks to the lucky rise in oil prices on the international market, the religious and "trabendist" middle classes completely swung towards le pouvoir and became its base of support. The abundance of rent enabled a pragmatic alliance between le pouvoir and the religious middle classes. Across the import sector, a group of import barons gathered around the president. Profiting from the abundance of foreign currency, they flooded the Algerian market with consumer goods. Surrounding those barons and benefiting from them, a stratum of small- and medium-scale merchants became active in the informal and formal sectors. They specialized in reselling imported products at a smaller scale. Thus, in addition to the traditional power centers (the army and the secret service), a new power center was born, this time around the president and the import barons. The country spends around 10 billion dollars per year on imported food products alone. The import sector is a lucrative business for certain circles close to power and plays a stabilizing role that, in times of high rent, keeps all the clans satisfied. According to the national press, 25,000 individuals have a stran- 
glehold on import licenses. In one of his first speeches, President Bouteflika himself claimed that 15 men controlled the entire country. In parallel, an important informal sector emerged. More than half of Algerian commerce is informal. Altogether, the quantity of small shops and retail establishments more than doubled from 2001 to 2010 to reach around 1.5 million.

Thus, a new social contract between the state and society was drawn up that generated a new middle class. This middle class is rent-seeking, as before, but it has a commercial character; I call it the "trabendist" middle class. "Crony capitalism" laid the foundations necessary for an ideological "new deal" between the nationalist profiteers of le pouvoir. Unlike the middle classes of the 1970s, who acquired their economic status through the labor, housing, and education policies of the state-as-provider, the middle classes of the 2000s drew their status from the direct and indirect distribution of rent, through commerce and public programs such as the youth employment agency. Ideologically, the middle classes of the 1970s took nationalist stances-a nationalism at times tinged with Pan-Arabism, or else Baathism - and were both pro-modernization and pro-development. Starting in the 2000s, the Algerian middle classes went through an interesting ideological mutation. On the one hand, there was a notable re-Islamization of day-to-day practices in a form clearly distinguishable from the traditional Islam as practiced by the previous generation. On the other, there was a rise in individualism and forms of consumption that mimicked Western styles.

This "trabendist" and profiteering middle class became an important actor in le pouvoir, forging a Trabendo-military-civil alliance in place of the military-technocratic-administrative coalition of the' $70 \mathrm{~s}$. "Bouteflikism" (Ouaissa 2019a) denotes the initiation of a brand of Trabendo capitalism based on imports. The ideologies of development and socio-Baathism were replaced with a new ideological cocktail. Bouteflikism brought Islamo-Baathists, nationalists, and secular Berbers under the same big tent. It is a patchwork ideology, tailored to neoliberalism but combining modernists and conservatives. Henceforth, the presidential coalition incorporates parties with mutually exclusive ideologies, such as the FLN, the RND, the Islamist TAJ (Rally of the Hope of Algeria), and the secular MPA (Popular Algerian Movement).

Besides erecting that civilian façade, President Bouteflika struck a wise peace deal with the institution of the military. By accepting his offer of greater financial autonomy, the army was overshadowed by politics. However, the budget of the Defense Ministry has seen astronomical increases since Bouteflika's rise to power. The 2019 national budget allocated 12 billion dollars to the army: some $320 \%$ more than in the year 2000 . Military spending now comprises nearly a quarter of the national budget. According to a 2016 ranking by the Stockholm 
International Peace Research Institute, based on its military spending, Algeria is the seventeenth strongest military power in the world and the strongest in Africa (Ouaissa 2019b). As such, the Algerian army is one of the institutions that benefits most from rent on natural gas and oil. According to the French Centre de Ressources et d'Information sur l'Intelligence Économique et Stratégique, the Algerian army massively invests its resources in the development of its defense industry (Carol 2018).

Since mid-2014, the price of oil has fallen precipitously, and Algeria is now living through a moment comparable to 1988. Rent from oil is no longer enough to co-opt the deadlocked middle classes, nor can it buy the loyalty of different segments of society. The middle classes are witnessing a slow drop in their living standards. They reject the neoliberal ideology, as it only widened the gap that divides the richest stratum from the middle and lowest strata of society. Once again, the cohesion between the clans in le pouvoir is falling apart. In the absence of a shared political ideology, rent is the only common denominator among the clans of the state class. Since February 2019, a recomposition and re-configuration of the structure of the clans of le pouvoir has been underway (Ouaissa 2020). And as it has in every rentier crisis, the army has taken control of the political system; its staff has been the political decision-making body ever since the coup that overthrew President Bouteflika on April 2, 2019. As in the late 1980s, the middle classes are turning their backs on le pouvoir; they have become the driving force behind the Hirak protest movement.

The interim president, under orders from the military arm of le pouvoir, is attempting to simulate a transition. In fact, it is merely a re-configuration of the state class. Yet this time the prospect of re-configuring the system seems trickier because the middle classes of Hirak are determined to push through a real transition.

\section{Hirak: A New Kind of Protest Movement}

Hirak is a new, atypical kind of social movement that defies traditional theories of social movements (Volpi 2019). Over a few months of protests, Hirak overturned not only the political order of state and society as established after 1962, but also the structure of the clans in le pouvoir. What is more, Hirak successfully rewrote Algerian society's collective memory to establish itself as a precursor of a new society to come. Hirak has provoked what Frantz Fanon termed a "double rupture" (Fanon 2002). In the first rupture, Algerians reject the hatred and distrust 
that le pouvoir had sown among them. In the second, they redirect that hatred against le pouvoir itself.

Unlike the base of the previous protest movement during the 1980s, which mostly consisted of culturally and economically marginalized groups such as the "hittists"2 and "trabendists," Hirak's base is made up of middle-class people whose progress had been deadlocked. The actors involved in the movement are linked to the modes of consumption prevalent among the middle strata of society, although this position is more subjective than socioeconomic: by all accounts, the protesters are economically unstable. Thus, the Algerian middle classes seem to be wedged into the space between precarity and individualistic trends (Estanque 2015). The middle classes can be broken down into three identifiable segments: the new middle class, generally employed in nonproductive sectors of the economy; relics of the old middle class (farmers, traders, artisan producers, public sector employees); and a "peripheral" population composed of people with little involvement in the labor market (students, homemakers, and retirees).

Characterized by spontaneity and its lack of structure, this movement has managed to bypass the authoritarian regime's attempts at security measures, manipulation, infiltration, and co-option. Distinguishing itself from conventional protest movements that are organized by opposition political parties and organizations, Hirak put the regime on the defensive. Moreover, the political elite was unable to regain legitimacy by organizing elections because the movement sweepingly rejects the whole system and all its past practices, including the electoral system. The movement represents a form of collective action, and its repertoire of novel protest methods (songs, poetry, street theater, dance, and humor) paves the way for a flourishing of individual creativity and the popular genius. The middle-class movement frames problems in terms of values, reflecting the cultural context of its adherents. Unlike the movement of October 1988, whose actors were guided by dreams of personal advancement and confronted le pouvoir head-on, Hirak embodies goals and categories of actions stemming from middle-class culture, imbued with a certain professionalism. Though dominated by the middle classes, the movement is pursuing objectives that are more universal and global and transcend class boundaries. This reflects values associated with middle-class culture and education levels.

Unlike traditional social movements, Hirak's cohesion does not rest on serving individual interests. The group is rooted in a collective identity that cuts across specific ethnic, religious, or regional affiliations. Hirak recreates Algerianness in its diversity and all its historical dimensions. In reclaiming historical figures from the war of independence, in depoliticizing religion, and in proclaiming the Amazigh identity of the Algerian people across the country, the movement strips 
le pouvoir of the narratives that once legitimized its authoritarian rule for a long time. Hirak has endowed Algerian society with a national identity that is the outcome of change, negotiation, and communication among citizens. Collective action and shared experiences are constructing a new consciousness. As an inherently anti-establishment and anti-hegemonic social movement, Hirak is fighting not only to take back the material structure of production, but also to wrest control over socioeconomic development. In other words, it is seeking to reclaim individuals' day-to-day control over their time, space, and relationships (Melucci 1982, p. 219). Unlike the agendas of older movements that have existed in Algeria since 1962, Hirak's stated objectives cross class and regional lines.

Spontaneity lends autonomy and flexibility to the actors of Hirak, making it hard for le pouvoir to exert its habitual mechanisms of control or to measure the true force of the movement. The movement is decentralized, with neither a declared leadership nor a declared ideology, so that each citizen, across social networks, feels a personal sense of responsibility and concern. Participation is not tied to a centralized hierarchy. This explains the maturing self-image of the Algerian people and its rejection of Zaimist (elitist) culture. The movement's fluidity enables anyone to take part, to introduce themselves, or to propose slogans. At the same time, this spontaneity fits into weekly rituals that close out the Friday and Tuesday marches: ululations, the sounds of the mahraz (mortars and pestles), ${ }^{4}$ and "casserole"5 sessions on Thursday evenings. This is "ritualized spontaneity," formalized mass responses to the week's events or to decisions by le pouvoir. Hirak has inaugurated a new form of political dialogue between le pouvoir and the protesting masses: a dialogue across different spaces that is reminiscent of Frantz Fanon's topology of the colonial city, ${ }^{6}$ built around a spatial and psychological binary. Since February 2019, Algeria has been a compartmentalized realm, bisected into two different living spaces - the world of the incumbent pouvoir and the world of the people-which follow different logic and hold different visions of Algeria. Neither of these two worlds knows or recognizes the other: le pouvoir in their barracks and palaces, "the people" in their streets and public spaces. The institutions of the state are pitted against the will of the people and against the fulfillment of that will. The parliament, conceived to represent the people, absurdly keeps out of the conflict. The army, having missed the opportunity to play a nobler role, cut its umbilical cord to the people with the actions of its late leader. The president, who is nothing but a figurehead of the system's continuity, emerged out of the surrealism of a theatrical election. Faced with this political backwardness, Hirak is attempting to reconstruct the society it desires: a society built on tolerance, justice, and modernity. 


\section{Endnotes}

1. Designates informal economic activities und black market goods in Algeria.

2. The term "hittists," whose literal Arabic etymology means "those with their back against the wall," refers to unemployed teenagers clustered along an alleyway: marginalized youth.

3. This word designates social actors with professional qualifications who, seeking a share of the rent, rebel against the state-which is no longer capable of co-opting them-and turn to the informal sector instead.

4. A mortar and pestle are used to crush a substance into a paste or a powder. During the French colonial period, Algerian women used them to symbolize their solidarity with Algerian prisoners.

5. A cacerolazo, or casserole, is a form of noisy protest popular in Venezuela, Chile, Argentina, and Catalonia and practiced predominantly by the middle class. This form of demonstration also drew international attention during the last major economic crisis in Argentina. The name comes from the Spanish word cacerola, meaning stew pot, because a key element of these demonstrations is making noise using pots and pans. The message is often that "the pots are empty": there is nothing to eat. This form of protest can be traced back to the discontent of middle-class Chilean women under the socialist administration of Salvador Allende, when it was used in protest against food shortages and the ensuing rationing.

6. Frantz Fanon: Les damnés de la terre, p. 70.

\section{References}

Bennoune, Mahfoud. 1998. Esquisse d'une anthropologie de l'Algérie politique. Illustrée par une stratégie algérienne de sortie de la crise (acceptée, puis abandonnée par un pouvoir inapte). Algiers: Edition Marinoor.

Carol, Sylvestre. 2018. L'industrie de défense du colosse africain ou comment l'Algérie achète son indépendance stratégique. Portail de l'IE. https://portail-ie.fr/analysis/2005/ lindustrie-de-defense-du-colosse-africain-ou-comment-lalgerie-achete-son-independance-strategique. Accessed 25 May 2020.

Crisis Group. 2018. Surmonter la paralysie économique de l'Algérie. Rapport Moyen-Orient et Afrique du Nord de Crisis Group N 192.

Elias, Norbert. 2003. Figuration. In Grundbegriffe der Soziologie, Ed. Bernhard Schäfers, 88-91. Stuttgart: Leske+Budrich (Utb).

Elsenhans, Hartmut. 1996. State, class and development. New Delhi: Radiant Publ.

Estanque, E. 2015. Middle-class rebellions? Precarious employment and social movements in Portugal and Brazil (2011-2013). RCCS Annual Review 7: 17-44.

Fanon, Frantz. 2002 [1961]. Les Damnés de la Terre. Paris: La Découverte poche. 
Gellner, Ernest. 1981. The muslim society. New York: Cambridge University Press.

Hobsbawm, Eric J. 1987. The age of empire: 1875-1914. London: Weidenfeld \& Nicolson.

Linz, Juan, and A. Stepan. 1996. Problems of democratic transition and consolidation: Southern Europe, South America, and post-communist Europe. Baltimore: The Johns Hopkins University Press.

Melucci, A. 1982. The new social movements: A theoretical approach. Social Science Information 19:199-226.

Nashashibi, Karim, P. Alonson-Gamo, S. Bazzoni, A. Féler, N. Laframboise, and P. Horvitz. 1998. Algeria: Stabilization and transition to the market. Washington DC: International Monetary Fund.

Ouaissa, R. 2018. Classes moyennes algériennes, rente et stagnation politique. NAQD $36: 123-145$.

Ouaissa, R. 2019a. Le bouteflikisme c'est quoi? Le Matin d'Algérie. https://www.lematindalgerie.com/le-bouteflikisme-cest-quoi. Accessed 3 Mar 2019.

Ouaissa, R. 2019b. Algérie: quel rôle pour l'armée dans la transition démocratique? Telos. https://www.telos-eu.com/fr/politique-francaise-et-internationale/algerie-quel-rolepour-larmee-dans-la-transition-d.html. Accessed 6 May 2019.

Ouaissa, R. 2020. Une Algérie nouvelle, entre transition et reconfiguration. Le hirak échappe aux théorie classiques des mouvements sociaux. Liberté. https://www.libertealgerie.com/contribution/le-hirak-echappe-aux-theories-classiques-des-mouvements-sociaux-334025. Accessed 17 Feb 2020.

Ross, M.L. 2001. Does oil hinder democracy? World Politics 53:335.

Tönnies, Ferdinand. 2012. In Studien zu Gemeinschaft und Gesellschaft. Ed. Klas Lichtblau. Wiesbaden: VS Verlag.

Volpi, F. 2019. Le mouvement protestataire algérien de 2019 à la lumière de la théorie des mouvements sociaux et des Printemps arabes. L'Année du Maghreb 21. doi: 10.4000/ anneemaghreb.5039.

Rachid Ouaissa is professor of Near and Middle Eastern Politics at the Center for Near and Middle Eastern Studies at Philipps-Universität Marburg (Germany). His main fields of research are political, economic and societal developments in the MENA region, the rise and transformation of Islamist movements, and rentier states and the role of middle classes. Since February 2013, he served as spokesperson for the research network "Re-Configurations". Since April 2020, he is also director of the Merian Centre for Advanced Studies in the Maghreb (MECAM) in Tunis. 
Open Access This chapter is licensed under the terms of the Creative Commons Attribution 4.0 International License (http://creativecommons.org/licenses/by/4.0/), which permits use, sharing, adaptation, distribution and reproduction in any medium or format, as long as you give appropriate credit to the original author(s) and the source, provide a link to the Creative Commons license and indicate if changes were made.

The images or other third party material in this chapter are included in the chapter's Creative Commons license, unless indicated otherwise in a credit line to the material. If material is not included in the chapter's Creative Commons license and your intended use is not permitted by statutory regulation or exceeds the permitted use, you will need to obtain permission directly from the copyright holder.

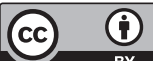

